\title{
口腔底蜂窩織炎14例に関する臨床的考察
}

\author{
南定・飯田順・竹山勇

\section{Clinical Findings of 14 Cases of Ludwig's Angina}

\author{
Sadamu Minami, Jun Iida and Isamu Takeyama \\ (St. Marianna University School of Medicine)
}

\begin{abstract}
We experienced 14 cases of Ludwig's angina disease between March, 1974 and February, 1987. Of the 14 patients, 9 were men, and 5 were women (mean age 36.3 years old). Except for two unknown cases all were related to dental disease, most of which were due to wisdom teeth and the first and the second molar teeth. In the operation for the swelling part, 11 cases were cut out and 3 cases were not cut out. Of the 11 cut cases 6 cases were festered. The bacteria in the pus were identified $\alpha$-strept which was popular. As for fever of the patients, all the patients had a fever over $37.0^{\circ} \mathrm{C}$ except in one case. Most patients visited hospital with in 3 to 5 days of onset, with an average of 5 days. Average stay in hospital was 25.5 days. They left the hospital within half a month except for the severe case such as diabetes mellitus. For therapy, the body should be rested, and extensive spectoral antibiotics should be administered for the protection of anaerobic bacterial infection. We have to consider the rapid advance of infection and the significance of the local incisions.
\end{abstract}

Key words: Ludwig's angina, deep neck infection, phregmon, abscess

\section{はじめに}

口腔底蜂窩織炎は別名 Ludwig's angina とも 呼ばれ, 1936年 Willhelm Frederich von Ludwigl) が咽頭丹毒より誘発された頸部壊疽 性組織硬結の一例を報告し, その後 Davis ${ }^{2)}$,

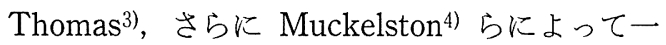
つの独立疾患として確立された。本邦において も1920年代より数多くの報告が見られ, 当時は 死亡率の極めて高い疾患であった。しかし，そ の後は抗生物質等の急速な発達により死亡例も 減少し，1960年以降本邦に打ける報告は歯科, 内科領域で散見されるものの, 耳鼻咽喉科領域 での報告は私共が渉猟しえた限りでは洼とんど 見られない。
今回私共は, 1974年開院時より1987年 2 月ま でに経験し入院治療を必要とした症例について 若干の文献的考察を加え報告する。

\section{症例}

今回我々の経験した症例は, 表 1 の如く 14 症 例で，男性 9 例，女性 5 例と男性に多い傾向が 見られ，年齢については特に好発年龄は認めら れず，平均36.3歳であった，原因については 2 例の不明例を除いてすべて歯牙に関係しており 抜歯後が 6 例, 齛歯が 6 例でめり, 歯牙の部位 に関してはそのほとんどが，智歯及び第一，第 二大臼歯が原因であった. 局所切開の有無につ いては切開11例, 未切開 3 例で, 切開11例中 7 例に排膿が認められた。発熱に関しては 1 例を 


\begin{tabular}{|c|c|c|c|c|c|c|c|c|c|c|}
\hline 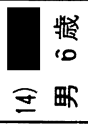 & 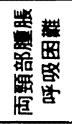 & $\begin{array}{l}0 \\
\dot{q}\end{array}$ & $\begin{array}{l}\text { 畄 } \\
k\end{array}$ & 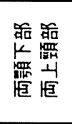 & $\nabla$ & $\stackrel{\varrho}{\varrho}$ & 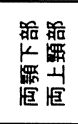 & 贯 & & I \\
\hline 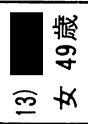 & 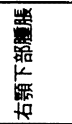 & $\begin{array}{l}\infty \\
\infty \\
\infty\end{array}$ & $\begin{array}{l}\text { 䊩 } \\
n\end{array}$ & 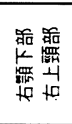 & 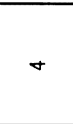 & $\simeq$ & 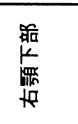 & 帮 & & I \\
\hline 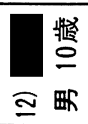 & 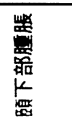 & $\begin{array}{l}0 \\
\dot{m}\end{array}$ & 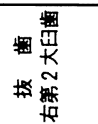 & 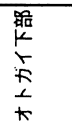 & $m$ & $\sigma$ & 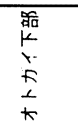 & 帮 & & I \\
\hline $\begin{aligned} & \frac{\text { 將 }}{m} \\
& \text { 三 㧽 } \\
&\end{aligned}$ & 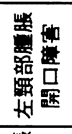 & $\stackrel{\sim}{\infty}$ & 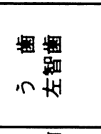 & 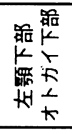 & $m$ & జ & 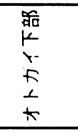 & II & 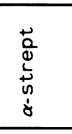 & 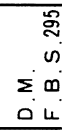 \\
\hline 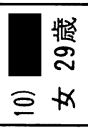 & 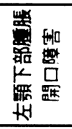 & $\hat{\dot{m}}$ & 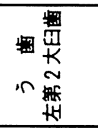 & 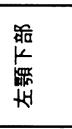 & in & in & I & & & I \\
\hline 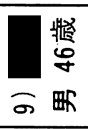 & 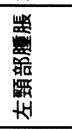 & m & 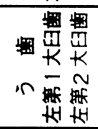 & 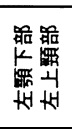 & m & $\simeq$ & 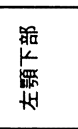 & fII & 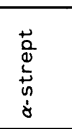 & I \\
\hline 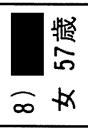 & 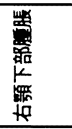 & $\stackrel{n}{\infty}$ & 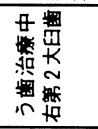 & 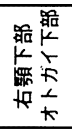 & $\omega$ & $\infty$ & 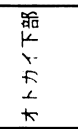 & If & 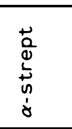 & I \\
\hline 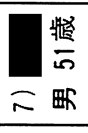 & $\begin{array}{l}\text { 率 } \\
\text { 罢 } \\
\text { 兽 }\end{array}$ & 일 & 数 & 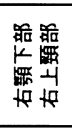 & n & ஜ & 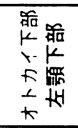 & III & 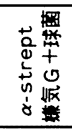 & 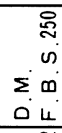 \\
\hline 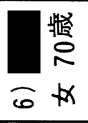 & 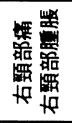 & $\stackrel{0}{\hat{m}}$ & 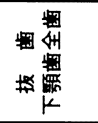 & 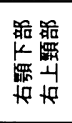 & $\sim$ & $\bar{m}$ & 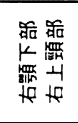 & tw & 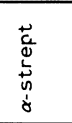 & $\begin{array}{r}\frac{N}{N} \\
i \\
\sum 0 \\
0 \\
0 \\
0\end{array}$ \\
\hline 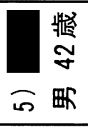 & 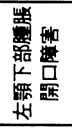 & 官 & 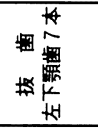 & 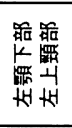 & $\theta$ & 0 & I & & & I \\
\hline 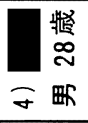 & 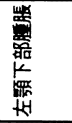 & $\stackrel{\infty}{\dot{m}}$ & 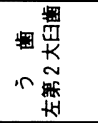 & 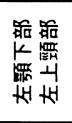 & $\sigma$ & $\simeq$ & 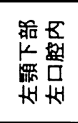 & III & $\begin{array}{l}\overrightarrow{0} \\
0 \\
0 \\
0 \\
0 \\
\dot{d}\end{array}$ & I \\
\hline 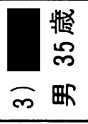 & 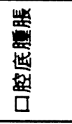 & 吕 & 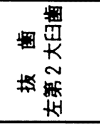 & 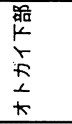 & $m$ & 으 & 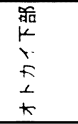 & 夥 & & I \\
\hline 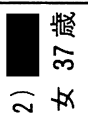 & 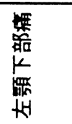 & $\overline{\hat{m}}$ & 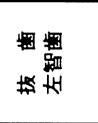 & 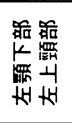 & \pm & $\infty$ & I & & & I \\
\hline $\begin{aligned} & \text { 將 } \\
& \infty \\
&= \text { 凅 } \\
&\end{aligned}$ & 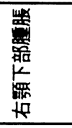 & 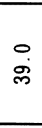 & $\begin{array}{l}\text { ⿳⼝ㅛ } \\
k\end{array}$ & 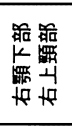 & 은 & \pm & 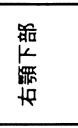 & II & 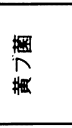 & I \\
\hline 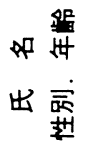 & $\begin{array}{l}\text { 此 } \\
\text { H }\end{array}$ & $\begin{array}{l}\widehat{U} \\
\text { 荡 } \\
\text { 㕲 }\end{array}$ & 因 & 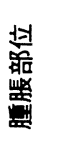 & 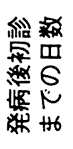 & 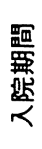 & 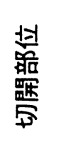 & 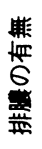 & $\begin{array}{l}\text { 㮯 } \\
\text { 治 } \\
\text { 踩 }\end{array}$ & 紫 \\
\hline
\end{tabular}


除いて注とんどが37.0度以上を示し，39.0度以 上ものが 6 例あった。発病後初診までの平均日 数は 5.0 日, 平均入院期間は 25.5 日で，糖尿病 合併の重症例を除いてそのほとんどが，半月以 内に退院した。ただし，若年性関節リュウマチ を合併したために入院が長引いた一症例（症例 14）はこの平均には含まれていない，以上をま とめると表 2 の如くである．排膿液の細菌培湌 同定の結果では $\alpha$-strept 等の常在菌が法とんど で，嫌気性菌は一例のみであった（表 3 ）。こ の嫌気性菌が同定された一例は，呼吸困難から 縱隔洞炎を併発し極めて重篤な経過を辿った。

表 2 自験例

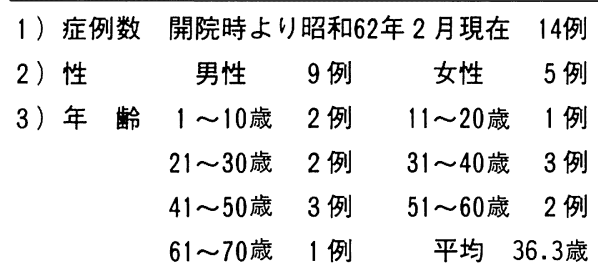

4) 原因不明 2 例

歯牙 12例 拢歯後 6 例 う歯 (治療含) 6 例

5）切開の有無 有 11 例(うち排膿 7 例)

6) 体 温 $36.9^{\circ} \mathrm{C}$ 以下 1 例 $37.0 \sim 37.4^{\circ} \mathrm{C} 2$ 例 $37.5 \sim 37.9^{\circ} \mathrm{C} \quad 2$ 例 $38.0 \sim 38.4^{\circ} \mathrm{C} \quad 1$ 例 $38.5 \sim 38.9^{\circ} \mathrm{C} 2$ 例 $39.0^{\circ} \mathrm{C}$ 以上 6 例

7 ) 発病後初診までの平均日数 5.0 日

8）平均入院日数

25.5日

（症例14は除く）

表 3 起炎菌

\begin{tabular}{|c|c|c|}
\hline & 自験例 & 後藤 (1938) \\
\hline 連鎖球菌 & $\begin{array}{c}6 \\
(\alpha \text { 連鎖球菌) }\end{array}$ & 13 \\
\hline ブドウ状球菌 & $\begin{array}{c}1 \\
\text { (黄ブ菌) }\end{array}$ & 12 \\
\hline 嫌気性菌 & 1 & 0 \\
\hline その他 & 0 & 3 \\
\hline
\end{tabular}

考察

口腔底蜂窩織炎は別名 Ludwig's angina とも 呼ばれ，時に呼吸困難等の重篤な症状を併発す ることもあり，耳鼻咽喉科領域では緊急処置を 要する疾患の一つとされている，今回，私共が 経験した症例では男性に多い傾向が見られたが， これは後藤5)や川島6) の報告でもそれぞれ男性 14例，女性10例，男性12例，女性 3 例と男性に 多い傾向が見られている．年龄に関する過去の 報告では，やや20代に多い傾向が見られるもの の，自験例では特に好発年齢は認められなかっ た.

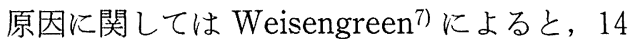
症例のらち12例が歯牙に関連しており，下顎大 臼歯が原因と考兄られたものが 9 例で，今回の 報告と同様の傾向が見られている.

後藤5)によれば起炎菌のほとんどは溶血性連 鎖球菌とブドウ状球菌であり，それらの混合感 染を起こしている場合もあり（表 3 ），嫌気性 菌によるものが重症になりやすいとされている。 これは今回の報告でも同様の結果が見られ， $\alpha$ strept 等の常在菌が洼とんどであり, 嫌気性菌 は一例のみで，極めて重篤な経過をたどった。

入院期間に関しては，糖尿病合併症例が重症 で長期入院となっており, 基礎疾患の有無が予 後を左右する重要因子の一つであると考觉られ た。

治療としては，先ず安静と嫌気性菌を考慮し ての広域スペクトル抗生物質や，局所の強度腫 脹に関してステロイド等の投与を行ない，感染 の急速な進行を予防するため局所の切開を行な らことが重要と考える. 今回の症例で，14例中 11例に切開を施行したが，切開の適応について は成書にもその方針は明確にされていない，幸 い自験例の中で切開をせず軽快の転帰をとった 症例もあり，一概には言えないが，原則として は切開すべきと考えている．切開部位に関して は顎下部，頋下部等の頸部の腫脹を来す症例に ついては, 腫脹部位の皮膚切開を, また, 舌下 部のみに限局している場合には口腔底の切開を 
すべきかと考光ている。

図 1 は，自験例に扮ける頸部単純レントゲン 撮影で，しばしばこのようにガス気泡が証明さ れる. 今回の症例中 $6,7,9,11$ の計 4 例にガ ス気泡が認められた。このような場合，嫌気性 菌の存在が示唆されるが，培養検査を施行して みると嫌気性菌は同定できない場合が多い。こ れは来院時までに他院にて抗生剤の投与を受け ていたり，また，急患にて時間外に来院するこ とが多いため，適切な嫌気培養ができていない こと等が考えられる.
口腔底蜂窩織炎といら名称は成書に执いても しばしばロ腔底膿瘍に対して用いられたり，ま た，口腔底に限らず顎下部等の蜂窩織炎を含め て取り扱われていることも多いよらである。

Ludwing's angina は舌下間隙と䫇下間隙に特 よぶ蜂窩織炎と考兄られているため, 厳密に言 らと両者は別の疾患と言光る。そこで先ず，口 腔底蜂窩織炎の定義について改めて検討したい と思う。

口腔底とは局所解剖学には, 上方が舌下粘膜, 下方は顎舌骨筋, 側方は下顎骨に囲まれた間隙

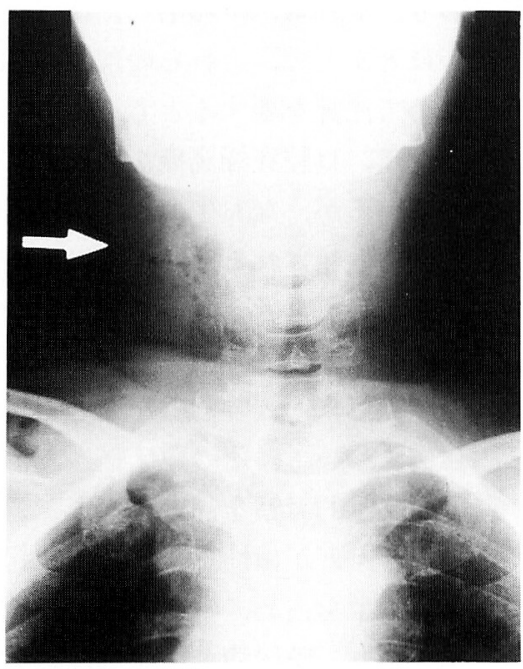

(a)

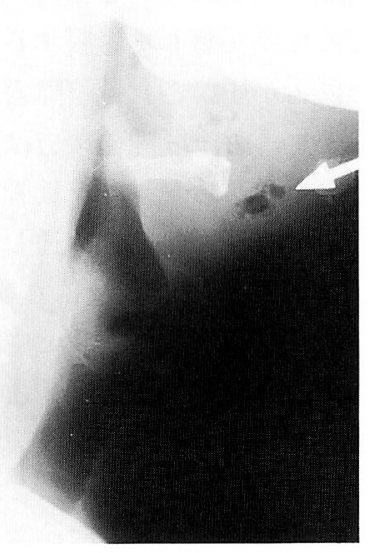

(b)

図 1 頸部レントゲン

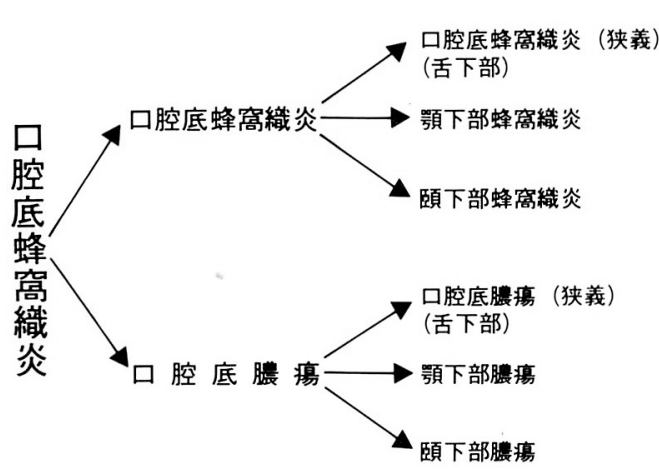

図 2 口腔底蜂窩織炎の分類

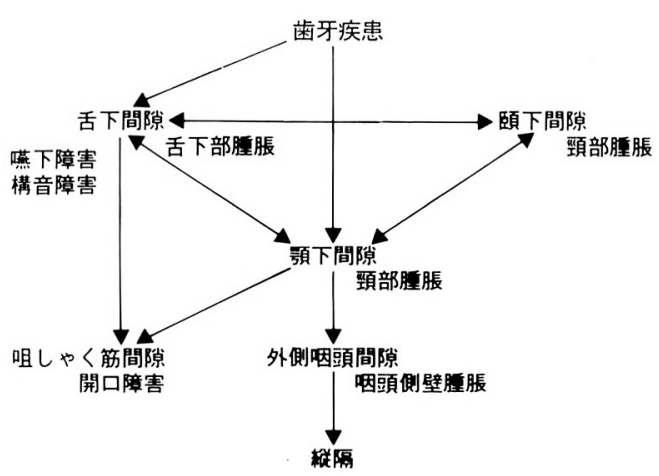

図 3 炎症の広がりと症状 
で, 舌下間隙とも呼ばれており, 厳密には口腔 底蜂窩織炎は，この部位に限局した疾患と言え る. 従って，願下部や顎下部に炎症があれば， それぞれ，頋下部蜂窩織炎，顎下部蜂窩織炎之 するのが適切と思われる8). また, 膿の存在が 認められれば, 病理学的な定義からすると蜂窩 織炎ではなく膿瘍とすべきと考える。しかし， 今回の14症例は広義に解釈し, これらの蜂窩織 炎や膿瘍をすべて口腔底蜂窩織炎として検討し た（図 2 ).ここで解剖学的相互関係と症状に ついて考皇たい，舌下間隙は，顎下間隙や贿下 間隙と交通して和り，これらの部位は容易に炎 症の波及を来しやすい，舌下間隙には舌下腺， 舌神経, 舌動静脈が存在し, 外側及び底後方が 比較的強い組織で囲まれているため, 炎症が起 こると舌下面の粘膜が著しく腫脹するのが特徵 で，そのために舌が圧排され曣下障害や構音障 害が起こる. また, 舌下間隙の後方は顎舌骨筋 の後縁となり，そこからワルトン氏管が顎下間 隙に入っているため，この部位を通して顎下間 隙に感染し，また，その逆も起こりらる ${ }^{9)}$ 。顎 下間隙は下顎底及び顎二腹筋前腹と中間腱で形 成された三角形で, 内面の前部は顎舌骨筋, 後 部は舌骨舌筋よりなり, 浅頸筋膜浅層に覆われ て打り顎下腺が存在する。そして，これらの間 隙の後方は咀嚼筋間隙に交通しているため, こ の部位に炎症が波及すると開口障害が生じる. また, 咀嚼筋間隙を舌神経, 舌動静脈等が通過 しており，感染もこれに沿って外側咽頭間隙に まで及ぶと極めて重篤となる，以上をまとめる と図 3 の如くである.

顎下間隙と舌下間隙の炎症は歯性感染がその 原因の大部分であるが，歯牙の種類によってど の間隙を侵すかが決まり，それは顎舌骨筋の起 始する位置による．すなわち，顎舌骨筋は後方 に行くに従い下顎の高い位置に起始部があるの で，第二大臼歯より前歯では顎舌骨筋より上方 の舌下間隙を，第二大臼歯及び智歯からは顎舌 骨筋より下方にある䫇下間隙を直接に侵すこと が多い。頋下間隙は, 左右の顎二腹笳前腹内側
縁と舌骨体部で囲まれた部分で上方の顎舌骨筋 下面と，下方の深頸筋膜浅層の間隙で，願下間 隙とは第二腹筋前腹を通って連絡するため両者 は互いに炎症が移行しやすく，また，個体によ って顎舌骨筋前 $1 / 3$ は筋束間が薄く, 時に筋束 の欠損を見られるため舌下間隙と交通し, 舌下 間隙の炎症が直接頙下間隙に波及することも考 えられる9). 以上のように, その解剖学的位置 関係と症状には密接な関係があるといえる.

原因に関して，文献的には扁桃周囲膿瘍，口 腔内外傷，下顎骨折などの報告10) も見られる が，自験例を含めその大部分が歯牙に関係して おり，それも，下顎第一，第二大臼歯及び智歯

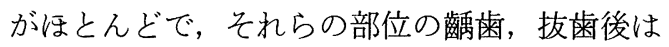
極めて注意を要すると考える.

近年, 口腔底蜂窩織炎の死亡率は極めて低下 しているが，な拉生命の危険性は否定できず死 亡例も散見されるため, その治療法には細心の 注意が必要と考える。

$$
\text { まとめ }
$$

開院以来，入院治療を要した口腔底蜂窩織炎 14例について, その臨床経過, 治療内容等を若 干の文献的考察を加え報告した. 本疾患の原因 は注とんどが歯性感染であり，起炎菌は連鎖球 菌が大半を占め, 嫌気性菌感染症例は重篤な経 過を辿り，糖尿病合併症例は重症であった。

なお，本論文の要旨は昭和 62 年度第 49 回耳鼻咽喉 科臨床学会において報告した。

\section{参考文献}

1) Ludwig WF : Ueber eine neue Art von Halsentzundung. Med Corr Blatt das Wurtemberg artzl Vereins $6: 21 \sim 25,1836$.

2) Davis GG: Acute septic infections of the throat and neck : Ludwig's angina. Ann Surg $44: 175 \sim 192,1906$.

3) Thomas TT : Ludwig's angina : An anatomical, clinical and statistical study. Ann Surg 48 : 788 790, 1908.

4) Muckleston HW : Angina Ludovici and kindred affections; historical and clinical study. 
Ann Otol Rhinol Laryngol 37 : 711 735, 1928.

5）後藤光治：歯牙とルードウィッヒ氏アンギーナ. 耳鼻臨床 $33: 89 \sim 94,1938$.

6）川島敏行 : Angina Ludovici に就て. 耳鼻臨床 $37:$ :990 997, 1942.

7) Weisengreen H Henry : Ludwig's angina; historical review and reflections. Ear Nose Throat J $65:$ 457 461, 1986.

8）毛利 学: 口腔底蜂窩織炎. 口腔底膿瘍. 図説 臨床耳鼻咽喉科講座. 第 4 巻. 26〜27頁, メジ
カルビュー社, 1983.

9）河村正三 : 感染解剖学 (靧下部, 口腔底). 耳 喉 $52: 10 ; 757 \sim 760,1980$.

10）西山喻義：ルードウィッヒ氏アンギーナの定義 に就て。耳鼻臨床 35 : 399 404, 1940.

$$
\left(\begin{array}{l}
\text { 別冊請求先 : 南 定 } \\
\text { 厂216 川崎市宮前区菅生 } 2-16-1 \\
\text { 聖マリアンナ矢科大学耳鼻咽喉科学教室 }
\end{array}\right)
$$

